\title{
Performance of supermarkets in Santa Catarina: an analysis of small and medium-sized units
}

\section{Desempenho dos supermercados de Santa Catarina: uma análise de pequenas e médias unidades}

\author{
Julio Cesar Araujo Silva Junior ${ }^{1}$, Douglas Nodari ${ }^{2}$, Mariana de Oliveira Cavalheiro ${ }^{3}$, \\ Fernanda Gomes Victor ${ }^{3}$ (D) \\ ${ }^{1}$ Universidade Federal de Viçosa - UFV, Programa de Mestrado em Economia, Departamento de Economia \\ Viçosa, MG, Brasil. E-mail: julio.econometria@gmail.com \\ 2Universidade Comunitária da Região de Chapecó - UNOCHAPECÓ, Faculdade de Ciências Econômicas, \\ Chapecó, SC, Brasil. E:mail: douglasn@unochapeco.edu.br \\ ${ }^{3}$ Universidade Federal do Rio Grande do Sul - UFRGS, Faculdade de Ciências Econômicas, Porto Alegre, RS \\ Brasil. E-mail: mariana_ocavalheiro@hotmail.com; fernanda.victor@ufrgs.br
}

How to cite: Silva Junior, J. C. A., Nodari, D., Cavalheiro, M. O., \& Victor, F. G. (2020). Performance of supermarkets in Santa Catarina: an analysis of small and medium-sized units. Gestão \& Produção, 27(4), e4685. https://doi.org/10.1590/0104-530X4685-20

\begin{abstract}
The retail supermarket sector is one of the most important in the third sector. Besides being one of that most generates direct and indirect jobs, it is one of the first to capture changes in consumer behavior. Given the strong competition and constant evolution of the sector, it is necessary to improve techniques for individual performance measurement of the networks and the construction of parameters of relative comparison between the units. The aim of this article is to analyze the efficiency of a 31 supermarkets sample in Santa Catarina, using Data Envelopment Analysis (DEA). The variables used in the investigation were gross sales, the number of employees, sales area and number of checkout's in the period of 2014 and 2015. The results pointed out a low percentage of units at maximum efficiency for the two periods analyzed. Another relevant finding was that the variables that presented a mismatch to reach the maximum efficiency of the units was the "Sales area $\left(\mathrm{m}^{2}\right)$ " and "number of employees", suggesting the existence of idle structure capacity.
\end{abstract}

Keywords: Data envelopment analysis; Efficiency; Supermarkets.

Resumo: O setor varejista de supermercados é de grande importância na geração de empregos e captação de mudanças no comportamento dos consumidores. Mudanças tecnológicas e mercadológicas ocorridas recentemente no setor aumentam a necessidade do aprimoramento de técnicas para a mensuração do desempenho individual das redes e a construção de parâmetros de comparação relativa entre as unidades. O objetivo deste artigo é analisar a eficiência de uma amostra de 31 supermercados de pequeno porte da região oeste de Santa Catarina. O método utilizado para a avaliação da eficiência foi a análise envoltória de dados $(D E A)$, com as variáveis: faturamento, número de funcionários, área de vendas e o número de checkout's, nos anos de 2014 e 2015. Os resultados encontrados apontaram para um baixo percentual de unidades em máxima eficiência de escala e técnica para os dois períodos analisados. Outra ponto relevante é a identificação das variáveis que apresentaram desajustes para o alcance da eficiência máxima das unidades (área de vendas e número de funcionários), sugerindo a existência de capacidade ociosa de estrutura.

Palavras-chave: Análise envoltória de dados; Eficiência; Supermercados.

Received Mar. 5, 2018 - Accepted May 26, 2018

Financial support: None.

This is an Open Access article distributed under the terms of the Creative Commons Attribution License, which permits unrestricted use, distribution, and reproduction in any medium, provided the original work is properly cited. 


\section{Introduction}

In Brazil, the third sector plays an important role in the generation of direct and indirect employment, besides having an expressive representativeness in the gross domestic product (GDP). The supermarket retail trade is part of this sector and, in 2015, represented about $5,4 \%$ of GDP, generating $R \$ 315,8$ billion in revenue and $7,1 \%$ in nominal annual growth - according to Brazilian Association of Supermarkets (ABRAS). Furthermore, despite economic retraction occurred in 2015, the supermarket trade has been one of the few sectors that has been creating jobs, with around 18.706 new jobs, as stated by DIEESE (2016).

The existence of large supermarket chains makes the industry market share concentrate in a small fraction of companies. According to Brazilian Association of Supermarkets, the top five networks in the ranking determined by the entity (which considers only gross sales) were responsible for more than half of the gross revenue of the entire sector in 2015. Souza et al. (2010) investigated the 100 smallest supermarket companies among the 300 largest in the sector and, comparing the 10 largest and the 10 smallest of this sample, found that the scale efficiency of the larger ones is relatively higher. Sonza \& Ceretta (2008) also showed similar results. However, in a regionally oligopolized market such as the supermarket, what happens among the group of small-sized companies? Do they make up a homogeneous and efficient group?

There are quite a few studies about small-sized supermarket units in the literature. In this sense, it is necessary to measure the efficiency of these productive units in order to obtain comparable indicators (benchmarks), and, thus, to be able to foment the debate on the differences between the results of this group of companies. This is relevant because, as claimed by Badin (1997), some companies are able to combine their inputs in a better way, using more appropriate processes and management techniques, generating products (outputs) with greater efficiency. About that, Silva \& Qassim (1994) argue that these companies would then serve as a reference to the others, who might consider revising their processes to optimize the performance of their enterprise.

With this purpose, Ferreira et al. (2009) made an analysis of efficiency of the Brazilian Association of Supermarkets ranking members based on the year of 2005. The authors found that only $2.34 \%$ of the 300 analyzed units presented full efficiency. However, they didn't aim to evidence the benchmarks resulting from the analysis or the variables that most influenced negatively to the inefficiency of most of the evaluated units. In this way, a deeper approach of these aspects is necessary in order to contribute to the management of this type of company, especially for the smaller-sized ones.

Given the above, this study aims to analyze the efficiency of small-sized supermarkets in Santa Catarina. And, specifically, check how the composition of sales area $\left(\mathrm{m}^{2}\right)$, number of checkouts and number of employees influence the efficiency (gross sales) in the years of 2014 and 2015. For this purpose, the Data Envelopment Analysis - DEA method was chosen. This method was chosen instead of the linear regression models because the latter presented some limitations and problems in the treatment of the data in question, such as multicollinearity between explanatory variables and a possible problem of endogeneity. Information about this method and its assumptions can be obtained from Johnston \& Dinardo (2001).

This study is justified by the fact that there are only a few researches that discuss the relative performance of small supermarkets, especially involving efficiency analysis 
techniques, multicriterial, in the Brazilian supermarket segment. The use of DEA allows analyzing and comparing several production units combining multiple variables without having to make any assumptions of functional forms for this. The use of this method is relevant since efficiency evaluation techniques are generally based on financial reporting. However, it is difficult to objectively clarify the operational efficiency behind the financial reports, since they cannot include a vision or analysis of the company's operational performance (Barros \& Alves, 2003). Barros (2006) highlights the need to look for the causes of the efficiency of this sector beyond internal management procedures, since it is not clear, ex ante, what these causes are.

The regional application is another contribution of this article, preserving the regional aspects and making sure that there is no interference of information characteristic of other localities in the results of interest. Moreover, analyzing productivity and efficiency is an important activity in the field of commercial distribution (Parsons, 1997), having relevance both to the economic theorist and to the regulator of economic policies (Farrell, 1957).

Besides this introduction, this text is structured in five more sections. The second section approaches aspects of the DEA method. The third section discusses the theoretical framework, focusing on the conceptual aspects about efficiency measurement and highlighting the main distinctions between efficacy, in addition to a brief literature review. In the fourth, the methodological procedures used are described, while in the fifth part the results are presented and discussed. Finally, the conclusions and recommendations for the continuation of the research are presented.

\section{Data Envelopment Analysis (DEA)}

Among the several models and techniques used to evaluate the efficiency of productive units, one method that stands out is the Data Envelopment Analysis - DEA. This technique has been used in the evaluation of efficiency in different areas, since the seminal study of Charnes et al. (1978), for example, in the banking sector and in the relationship between corporate governance and corporate performance (see, Ferreira et al., 2013).

This method can be used to evaluate the relative efficiency of each production unit in relation to the others (Colin, 2007). DEA's results allow managers to "learn" from comparisons with the most efficient companies and allow them to apply the techniques of the most efficient companies in the less efficient ones. This kind of comparative analysis, using high-efficiency companies as a reference, is often referred to as benchmarking or best practice analysis.

Data Envelopment Analysis can be defined as a non-parametric method used to calculate the comparative efficiency of production units called Decision Making Unit - DMUs. To measure the efficiency of DMUS, the variables are classified into inputs and outputs and the efficiency of each DMU is calculated from the ratio of the weighted sums of outputs to the weighted sums of inputs. This method, according to Souza \& Wilhelm (2009), calculates a maximum performance measure for each DMU in among all others and can generate as results:

a) An envelopment surface (frontier) that will identify efficient and inefficient DMUs;

b) A measure of metric efficiency for each DMU (border distance, source and degree of inefficiency);

c) A projection of the DMU on the frontier; 
d) A reference set (specific units that a particular DMU is being compared to).

When considering a DMU as the most efficient among all others, the DEA model generates an empirical production frontier. In this frontier the projections can take two forms: oriented to the reduction of inputs, which calculates the maximum reduction of the input for the same production of outputs; and, the maximum expansion of outputs, calculating the maximum expansion of the outputs, given a certain use of inputs (Figueiredo \& Mello, 2009).

A standard formulation can be described according to Equation 1, presented by Colin (2007) and reproduced as follows:

$\eta=\frac{\text { market value of outputs }}{\text { market value of inputs }}$

where $\eta$ is the ability to transform inputs into outputs.

There are several models in DEA's method and they differ in the type of orientation given by the direction of the projection at the frontier and the assumption about the return of scale displayed by the production technologies (Souza \& Wilhelm, 2009). However, the most widely used models in the literature are CCR, developed by Charnes et al. (1978), and BCC, created by Banker et al. (1984).

The CCR model allows to evaluate the efficiency through the constant returns of scale, because this works with the proportionality. That is, variations of inputs cause proportional variations in the product. The CCR model projects points through radial expansion at the production frontier (Figueiredo \& Mello, 2009; Souza \& Wilhelm, 2009).

In contrast, the BCC model allows the production set to present variable returns of scale. This model estimates the pure technical efficiency, considering variable returns of scale and identifies if they are present in increasing, decreasing and constant gains of scales (Sonza \& Ceretta, 2008).

The evaluation of performance measures such as productivity, with only one input and one output, is relatively simple. However, this relationship becomes complex when more variables are included in the analysis, especially when they are input and/or output. "For this complexity, the creation of a productivity index requires the use of different weights that consider the use of different inputs and the production of different outputs" (Boueri et al. 2015, p. 271). However, Cooper et al. (2007) claim that it is possible to obtain these productivity indices through a virtual output index and a virtual input index in order to find the efficiency index for each unit. Therefore, Equations 2 to 4 can be used, cited by Boueri et al. (2015):

$\boldsymbol{I V P} \boldsymbol{P}_{i}=\boldsymbol{u}_{1} \boldsymbol{q}_{1, i}+\boldsymbol{u}_{2} \boldsymbol{q}_{2, i}+\ldots+\boldsymbol{u}_{s} \boldsymbol{q}_{s, i}$

where $q_{j, i}$ is the amount produced by the ith DMU of the product $\mathrm{j}$ in the index construction and $u_{j}$ is the weight assigned to the product in the index construction.

$I V I_{i}=v_{l} x_{l, i}+v_{2} x_{2, i}+\ldots+v_{m} x_{m, i}$ 
where $x_{j, i}$ is the quantity of inputs produced by the ith DMU of product $\mathrm{j}$ in the construction of the index and $v_{j}$ is the weight assigned to the input in the construction of the index.

Given this, the measurement of the productivity index is given by the ratio between virtual product index and virtual input index, as explained below:

$\theta_{i}=\frac{\boldsymbol{I V P} \boldsymbol{P}_{i}}{\boldsymbol{I V I _ { i }}}=\frac{u_{l} q_{l, i}+u_{2} q_{2, i}+\ldots+u_{s} q_{s, i}}{v_{l} x_{l, i}+v_{2} x_{2, i}+\ldots+v_{m} x_{m, i}}$

The main difficulty encountered in dealing with these models is to find the vectors of weight, in a non-arbitrary way, in order not to favor any unit. For this, the two classical models most used in this type of evaluation were developed by Charnes et al. (1978) - CCR model - and by Banker et al. (1984) - BCC model.

The orientation of these two models is also differentiated in relation to the focus of the measure of efficiency: either focused on the space of products or the space of inputs (oriented to input or output). To illustrate, the systems of Equations 5, 6 and 7 bring the input-oriented CCR and BCC models approach, in addition to the scale efficiency ratio, according to Boueri et al. (2015).

In the case of the CCR model with input orientation, the system (5) is as follows:

$$
\begin{aligned}
& \frac{\operatorname{Min}: \theta_{i}}{\{v, u\}}=\frac{u_{1 i} q_{1 i}+u_{2 i} q_{2 i}+\ldots+u_{s i} q_{s i}}{v_{l i} x_{1 i}+v_{2 i} x_{2 i}+\ldots+v_{m i} x_{m i}} \text { subject to } \frac{u_{l i} q_{1 j}+u_{2 i} q_{2 j}+\ldots+u_{s i} q_{s j}}{v_{l i} x_{1 j}+v_{2 i} x_{2 j}+\ldots+v_{m i} x_{m j}} \leq 1, \forall j=1,2, \ldots, n \\
& u_{l i}, u_{2 i}, \ldots u_{s i} \geq 0 e u_{i} \neq \overline{0} \quad v_{l i}, v_{2 i}, \ldots v_{m i} \geq 0 \text { e } v_{i} \neq \overline{0}
\end{aligned}
$$

In (5), it is possible to observe that the objective function of the problem is the efficiency level of the unit $i \frac{\operatorname{Min}: \theta_{i}}{\{v, u\}}=\frac{u_{1 i} q_{1 i}+u_{2 i} q_{2 i}+\ldots+u_{s i} q_{s i}}{v_{l i} x_{1 i}+v_{2 i} x_{2 i}+\ldots+v_{m i} x_{m i}}$ and suggests an optimal choice of possible weights for each unit ( $u$ and $v$ ). On the other hand, consistency constraints can be checked $\left(\frac{u_{l i} q_{1 j}+u_{2 i} q_{2 j}+\ldots+u_{s i} q_{s j}}{v_{l i} x_{l j}+v_{2 i} x_{2 j}+\ldots+v_{m i} x_{m j}} \leq 1, \forall j=1,2, \ldots, n\right)$, who determines that the weights, when used on the records of any other unit, cannot generate a value greater than the unity. The second restriction, called positivity condition $\left(u_{l i}, u_{2 i}, \ldots u_{s i} \geq 0 e u_{i} \neq \overline{0} ; v_{l i}, v_{2 i}, \ldots v_{m i} \geq 0\right.$ e $\left.v_{i} \neq 0\right)$, ensures that the weights are all non-negative, and that at least one input and one output are positively weighted in the condition of the index (Boueri et al., 2015).

When it comes to BCC model, which considers variable returns to scale, it can be applied by the system Equation 6:

$$
\frac{\text { Min }}{\theta, \lambda}: \theta_{i} \text { subject to } \theta_{i} \bar{X}_{I}-X \bar{\lambda} \geq \overline{0}_{m} Q \bar{\lambda}-\bar{q}_{i} \geq \overline{0}_{s} \bar{e}_{n} \bar{\lambda}=1 \bar{\lambda} \geq \overline{0}_{n}
$$

In this context, $\bar{e}_{n}$ is a vector of dimension $\mathrm{n}$ exclusively composed by unit value 1 . Besides that, there is a further restriction $\bar{e}_{n} \bar{\lambda}=\lambda_{1}+\lambda_{2}+\ldots+\lambda_{n}=1$ ), which in practice does 
not allow a DMU from being compared with others very different from it (Boueri et al. 2015).

Finally, the Equation 7 shows the mathematical model that measures the scale efficiency:

$$
E s=\frac{E t_{R C E}\left(X_{k}, Y_{k}\right)}{E t_{R V E}\left(X_{k}, Y_{k}\right)}
$$

where $E s$ is the scale efficiency's measurement; $E t_{R C E}\left(X_{k}, Y_{k}\right)$ is the technical efficiency (CCR) and $E t_{R V E}\left(X_{k}, Y_{k}\right)$ is the technical efficiency (BCC).

The BCC model results in a pure technical efficiency measure (isolating scale factors), unlike the CCR model. Equation 7 provides a measure, obtained by the ratio between the measures of technical efficiency in the models with constant and variable yields, that allows identifying if the DMUs are operating or not in their optimal scale (Ferreira \& Gomes, 2012).

\section{Efficiency and the supermarket sector}

Efficiency, according to Donthu \& Yoo (1998), can be considered as the relation between the weighted sum of outputs and inputs of a productive process. In this context, it refers to a judgment on the relation between the resources used (the inputs) and a measure of the results obtained (outputs). Moreno (2006) highlights the relationship between efficiency and productivity, stating that efficiency is a fundamental point in retail because it is a component of total productivity.

Although similar, the term efficiency should not be confused with effectiveness. Estrada \& Almeida (2007) define efficiency as the correct elaboration of a process or an activity. On the other hand, they argue that effectiveness is related to the simple achievement of objectives (or results) expected with the accomplishment of activities or processes. Szczepura et al. (1993) relate efficiency to the degree to which an organization uses its resources optimally to deliver its products or services and the effectiveness with the delivery of these services / products adequate.

Moreno (2008), on the other side, wrote about the concept of efficiency in hypermarkets, claiming that the efficiency of a hypermarket is a measure that compares how well it processes the inputs to achieve its outputs, considering its maximum potential to do so, being represented by its production possibilities frontier. However, a hypermarket can be technically inefficient if it operates below that frontier. Finally, in the context of DEA, efficiency means producing the maximum quantity of outputs for any quantity of inputs, or the minimum use of inputs for any quantity of outputs (Donthu \& Yoo, 1998).

In terms of efficiency categories, it can be classified as technical, allocative and economical, in which:

Technical efficiency: it reflects the ability of a firm to obtain maximum output from a given set of inputs. Allocation efficiency: reflects the ability of a firm to use inputs in optimal proportions, given their respective prices, minimizing costs. Finally, these two measures of efficiency are combined to obtain a final measure of total economic efficiency (Ferreira \& Gomes, 2012, p. 53). 
The term efficiency refers to microeconomic theory and it is related to the returns to scale that describe what happens to the product when the inputs change. Given this, returns to scale are typically more common in industry. However, Pindyck \& Rubinfeld (2010) assert that levels of returns to scale may vary between firms and sectors. Yet, the more substantial these returns are, the greater their participation in the sector tends to be.

In this sense, the concept of returns to scale deals with the relations of production over a wide time interval that allows variations in the quantities used of all productive inputs, especially those with physical space, parts of equipment and managerial capacity, which are typically fixed in the short run (Thompson \& Formby, 2003).

According to Varian (2012), returns can be segregated into constant returns to scale (in which the quantity of the product changes in the same proportion as the quantity of its inputs are changed) increasing returns to scale (when the return of the product is greater than the proportion of the inputs) and decreasing returns to scale (when the product changes less, in proportion to the inputs).

In turn, Pindyck \& Rubinfeld (2010) argue that increasing returns to scale may occur when the larger-scale operation allows administrators and employees to specialize and make better use of more specialized and large-scale facilities and equipment. However, they argue that in situations where there are constant returns to scale, the size of the firm does not interfere on the productivity of its inputs.

Moreover, as claimed by Thompson \& Formby (2003), five factors may contribute to increasing returns to scale. The first (and most important) are the opportunities created by specialization in the use of labor when a firm's scale of operations increases. Secondly, the higher the scale of operations, the easier it will be to use more advanced technologies. The third point is related to purely dimensional factors, while the fourth factor refers to the technological complex production process in which difficulties must be overcome. The fifth and last is tied to the use of talents in business administration.

On the other hand, there is a possibility of decreasing returns to scale, where production increases less than twice as much when the applied inputs are doubled. In this sense, Thompson \& Formby (2003) mention that the determining factor for this type of scale is the size of the company. The bigger the company, the greater the problems related to the integration of the various facets of the firm's activities. This is the limit on which the managerial function can be performed more efficiently.

Pindyck \& Rubinfeld (2010) report that declining returns to scale can be detected in companies with large-scale operations, because of the difficulties in organizing and managing operations. In this context, the occurrence of decreasing returns to scale is directly related to problems of task coordination and a good communication channel between administration and production.

In order to find previous studies that dealt with the subject in the field of supermarkets, online searches were carried out in May 2018 on the research platforms "Portal de Periodical Capes", "Scholar Google", "Scopus" "Web of Science", "Emerald" and "Scielo". From the searches in the databases the works shown in Chart 1 were found. 
Chart 1. Studies with similar focus.

\begin{tabular}{|c|c|c|}
\hline Authorship (Year) & Main informations & DEA Features \\
\hline Badin (1997) & $\begin{array}{l}\text { Evaluated the efficiency of the } \\
\text { supermarket sector through a } \\
\text { strategy that involved Data } \\
\text { Envelopment Analysis (DEA), } \\
\text { Benchmarking and Production } \\
\text { Function. Using data from } \\
\text { Brazilian Association of } \\
\text { Supermarkets ranking of } 1996 \text {, } \\
\text { it was observed that } 467 \\
\text { supermarkets, among } 600, \\
\text { could be considered inefficient. }\end{array}$ & $\begin{array}{l}\text { Model: BCC, with } \\
\text { input orientation and } \\
600 \text { DMUs. } \\
\text { Variables: } \mathrm{n}^{0} \text { of } \\
\text { checkout's, total store } \\
\text { area, } \mathrm{n}^{0} \text { of employees, } \\
\mathrm{n}^{0} \text { of stores and } \\
\text { average income per } \\
\text { capita (inputs) and } \\
\text { revenues (output). }\end{array}$ \\
\hline Barros \& Alves (2003) & $\begin{array}{l}\text { They analyzed the efficiency of } \\
\text { individual retail stores } \\
\text { belonging to a chain of } \\
\text { hypermarkets in Portugal. With } \\
\text { information from the year } \\
2000 \text {, they concluded that } \\
\text { more than } 63 \% \text { of the sample } \\
\text { was technically inefficient. }\end{array}$ & $\begin{array}{l}\text { Models: CCR e BCC, } \\
\text { with output orientation. } \\
\text { Variables: sales and } \\
\text { operational results } \\
\text { (outputs); full and part } \\
\text { time employees, labor } \\
\text { cost, absenteeism, } \\
\text { area, } \mathrm{n}^{0} \text { of the points } \\
\text { of sale, inventory e } \\
\text { other costs (inputs). } \\
\text { DMUs: } 47 \text {. }\end{array}$ \\
\hline Barros (2006) & $\begin{array}{l}\text { Checked the efficiency of } \\
\text { hypermarkets and } \\
\text { supermarkets in Portugal. He } \\
\text { adopted a two-step procedure } \\
\text { with DEA and Tobit models. } \\
\text { The findings showed that } \\
\text { larger retail groups are more } \\
\text { efficient than smaller retailers; } \\
\text { and that national retailers are } \\
\text { more efficient than regional } \\
\text { retailers. }\end{array}$ & $\begin{array}{l}\text { Models: CCR e BCC, } \\
\text { with output orientation. } \\
\text { Variables: } n^{0} \text { full time } \\
\text { employees and value } \\
\text { of assets (inputs); the } \\
\text { outputs were: sales, } \\
\text { operational results } \\
\text { and added value. } \\
\text { DMUs: } 132 \\
\text { (1 observation by } \\
\text { year, of } \\
22 \text { companies, } \\
\text { between 1998-2003). }\end{array}$ \\
\hline Sellers-Rubio \& Mas-Ruiz (2006) & $\begin{array}{l}\text { The authors estimated the } \\
\text { economic efficiency of the } \\
\text { supermarket chains of the } \\
\text { Spanish retail industry using } \\
\text { DEA. The sample consisted in } \\
100 \text { supermarket chains } \\
\text { between } 1995 \text { and } 2001 \text {. Their } \\
\text { results indicated high levels of } \\
\text { economic inefficiency in the } \\
\text { Spanish retail sector. }\end{array}$ & $\begin{array}{l}\text { Models: CCR e BCC, } \\
\text { with output orientation. } \\
\text { The inputs were: } n^{0} \text { de } \\
\text { employees, points of } \\
\text { sale and capital (own } \\
\text { funds and debt). } \\
\text { The outputs were } \\
\text { sales and profits. } \\
\text { DMUs: } 100 \text {. }\end{array}$ \\
\hline Didonet \& Villavicencio (2008) & $\begin{array}{l}\text { Didonet \& Villavicencio verified } \\
\text { the relationship between market } \\
\text { orientation components and their } \\
\text { efficiency in the supermarket } \\
\text { segment of Belo Horizonte, } \\
\text { using DEA and Tobit models. } \\
\text { The results indicated that } \\
\text { specific actions of generation } \\
\text { and dissemination of intelligence } \\
\text { have a positive influence on } \\
\text { efficiency levels. And that only } \\
17 \text { among } 67 \text { supermarkets } \\
\text { were efficient. }\end{array}$ & $\begin{array}{l}\text { Model: BCC with } \\
\text { output orientation. } \\
\text { Variables: } n^{\circ} \text { of } \\
\text { employees, } n^{\circ} \text { of } \\
\text { checkout's and area of } \\
\text { sales (inputs); and } \\
\text { average number of } \\
\text { customers and } \\
\text { average number of } \\
\text { products in stock } \\
\text { (outputs). DMUs: } 67 .\end{array}$ \\
\hline
\end{tabular}


Chart 1. Continued...

\begin{tabular}{|c|c|c|}
\hline Authorship (Year) & Main informations & DEA Features \\
\hline Moreno (2008) & $\begin{array}{l}\text { Analyzed the efficiency of } \\
\text { hypermarkets in Spain } \\
\text { focusing on state regulation of } \\
\text { the sector. The results } \\
\text { suggested that hypermarkets } \\
\text { operating in areas with low } \\
\text { regulatory constraints were } \\
\text { more efficient than those } \\
\text { located in areas of higher } \\
\text { regulation. }\end{array}$ & $\begin{array}{l}\text { Model: CCR with } \\
\text { output orientation. } \\
\text { Variables: inputs: } \\
\text { employees and area } \\
\text { m²; the output was } \text { sales. DMUs: } 234 \text {. }\end{array}$ \\
\hline Sonza \& Ceretta (2008) & $\begin{array}{l}\text { With data from the Brazilian } \\
\text { Association of Supermarkets } \\
\text { ranking, the authors verified } \\
\text { the relationship between } \\
\text { efficiency and size of } \\
\text { companies. They concluded } \\
\text { that large companies were } \\
\text { more efficient than others. }\end{array}$ & $\begin{array}{l}\text { Models: CCR e BCC, } \\
\text { with input and output } \\
\text { orientation. } \\
\text { Variables: sales area } \\
\text { per store, checkout's } \\
\text { and number of } \\
\text { employees; gross } \\
\text { sales and percentage } \\
\text { variation of gross } \\
\text { sales (outputs). } \\
\text { DMUs: } 500 .\end{array}$ \\
\hline Figueiredo \& Mello (2009) & $\begin{array}{l}\text { Figueiredo \& Mello have } \\
\text { generated a hybrid index of } \\
\text { efficiency and effectiveness } \\
\text { with a retail application. } \\
\text { The main contribution refers to } \\
\text { the use of artificial DMUs in } \\
\text { contexts where there are } \\
\text { multiple inputs and multiple } \\
\text { outputs. }\end{array}$ & $\begin{array}{l}\text { Model: BBC with input } \\
\text { orientation. } \\
\text { Variables: sales area } \\
\text { per store and } \mathrm{n}^{0} \text { of } \\
\text { employees (inputs); } \\
\text { gross sales and } \\
\text { number of served } \\
\text { clients (outputs). } \\
\text { DMUs: } 39 .\end{array}$ \\
\hline Ferreira et al. (2009) & $\begin{array}{l}\text { They analyzed the technical } \\
\text { and scale efficiency of the } \\
\text { Brazilian supermarket sector, } \\
\text { using data from the ABRAS } \\
\text { ranking of the year } 2005 \text {. They } \\
\text { found an association between } \\
\text { the technical efficiency and the } \\
\text { size of the supermarkets, in } \\
\text { addition to a low efficiency in } \\
\text { the sample analyzed. }\end{array}$ & $\begin{array}{l}\text { Models: CCR e BCC, } \\
\text { with output orientation. } \\
\text { Variables: } n^{\circ} \text { of } \\
\text { checkouts, } n^{0} \text { of } \\
\text { employees and total } \\
\text { used area (inputs); } \\
\text { gross annual sales of } \\
\text { supermarkets (output). } \\
\text { DMUs: } 300 .\end{array}$ \\
\hline Yu \& Ramanathan (2009) & $\begin{array}{l}\text { Yu \& Ramanathan evaluated } \\
\text { the operational efficiency of } \\
\text { retail companies in China } \\
\text { using three methodologies: } \\
\text { DEA, Malmquist Productivity } \\
\text { Index and Tobit model. } \\
\text { The period under investigation } \\
\text { comprised the years } 2000 \text { to } \\
2003 \text {. Their results indicate a } \\
\text { very small number of efficient } \\
\text { companies and an } \\
\text { improvement of } 37 \% \text { of the } \\
\text { companies investigated during } \\
\text { the period. }\end{array}$ & $\begin{array}{l}\text { Models: CCR e BCC, } \\
\text { with output orientation. } \\
\text { Variables: } \mathrm{n}^{0} \text { of } \\
\text { employees and total } \\
\text { area of sales (inputs) } \\
\text { and turnover and profit } \\
\text { before tax (outputs). } \\
\text { DMUs: } 61 .\end{array}$ \\
\hline Souza et al. (2010) & $\begin{array}{l}\text { They analyzed the } \\
\text { performance of the } \\
100 \text { smallest supermarket } \\
\text { companies among the } \\
300 \text { largest in } 2005 \text { in Brazil. }\end{array}$ & $\begin{array}{l}\text { Models: CCR e BCC, } \\
\text { with input orientation. } \\
\text { Variables: } n^{0} \text { of stores, } \\
n^{0} \text { of checkouts and } n^{0} \\
\text { of employees (inputs); }\end{array}$ \\
\hline
\end{tabular}


Chart 1. Continued...

\begin{tabular}{|c|c|c|}
\hline Authorship (Year) & Main informations & DEA Features \\
\hline & $\begin{array}{l}\text { The } 10 \text { largest supermarkets } \\
\text { performed better than the } \\
10 \text { smaller ones. All with one } \\
\text { store presented performance } \\
\text { problems related to the scale, } \\
\text { while those with more than one } \\
\text { presented problems related to } \\
\text { technical efficiency. }\end{array}$ & $\begin{array}{l}\text { and gross sales } \\
\text { (output). DMUs: } 100 .\end{array}$ \\
\hline Reiner et al. (2013) & $\begin{array}{l}\text { The researchers empirically } \\
\text { evaluated and quantified the } \\
\text { logistics processes of } \\
\text { supermarkets and } \\
\text { hypermarkets in a network in } \\
\text { Europe. The results indicate } \\
\text { different levels of efficiency for } \\
\text { different store formats. }\end{array}$ & $\begin{array}{l}\text { Model: BBC. } \\
\text { Variables: space, } \\
\text { employees and shelf } \\
\text { measurements } \\
\text { (inputs); turnover, } \\
\text { service level and } \\
\text { waste (outputs). } \\
\text { DMUs: } 202 .\end{array}$ \\
\hline Ko et al. (2017) & $\begin{array}{l}\text { They investigated the factors } \\
\text { that affect the efficiency of } \\
\text { chain stores in Korea, using } \\
\text { DEA and Tobit models. They } \\
\text { concluded that too many items } \\
\text { can reduce efficiency and that } \\
\text { competition helps improving } \\
\text { efficiency (to the point of } \\
\text { excessive competition). }\end{array}$ & $\begin{array}{l}\text { Model: BBC with } \\
\text { output orientation. } \\
\text { Variables: store size, } \\
\mathrm{n}^{0} \text { of items, } \mathrm{n}^{0} \text { of } \\
\text { employees and rent } \\
\text { cost (inputs); sales } \\
\text { revenue and } \mathrm{n}^{0} \text { of } \\
\text { clients (outputs) } \\
\text { DMUs: } 32 \text {. }\end{array}$ \\
\hline Sinik (2017) & $\begin{array}{l}\text { Evaluated the efficiency of } \\
\text { supermarkets in Austrian malls } \\
\text { in the year } 2015 \text {. The results } \\
\text { pointed to a high level of } \\
\text { efficiency (average of } 91 \% \text { ) in } \\
\text { the analyzed period. }\end{array}$ & $\begin{array}{l}\text { Models: CCR e BCC. } \\
\text { Variables: clients, } \\
\text { transactions size, } \\
\text { area, labor costs, } \\
\text { works hours, } \\
\text { productivity and loss } \\
\text { of stock (inputs); } \\
\text { turnover separated in } \\
\text { two departments } \\
\text { (output). DMUs: } 28 \text {. }\end{array}$ \\
\hline Melo et al. (2018) & $\begin{array}{l}\text { They evaluated the efficiency } \\
\text { of the Brazilian supermarket } \\
\text { sector and the changes in } \\
\text { productivity from } 2005 \text { to } 2012 \text {. } \\
\text { They found that the } \\
\text { supermarket chains have low } \\
\text { levels of average efficiency } \\
\text { and that there was an increase } \\
\text { of productivity in the period. } \\
\text { Small supermarket chains } \\
\text { showed the lowest levels of } \\
\text { efficiency in } 2005 \text { and } 2012 \text {, } \\
\text { but were the ones that } \\
\text { achieved the highest levels of } \\
\text { productivity growth in the } \\
\text { period. }\end{array}$ & $\begin{array}{l}\text { Model: Bootstrap Data } \\
\text { Envelopment } \\
\text { Analysis, with RCE } \\
\text { and RVE. } \\
\text { Variables: } \mathrm{n}^{0} \text { of } \\
\text { employees, } \mathrm{n}^{0} \text { of } \\
\text { checkout's and area of } \\
\text { store in } \mathrm{m}^{2} \text { (inputs); } \\
\text { annual gross sales } \\
\text { (output). } \\
\text { DMUs: in } 2005,494 \text {. } \\
\text { DMUs: in } 2012,701 .\end{array}$ \\
\hline
\end{tabular}

Source: Elaborated by authors.

Based on the above, a research gap was detected on the application of Data Envelopment Analysis in the context of smaller supermarkets in Santa Catarina, for which it was intended to contribute in this study in the sense of minimizing it. Additionally, these geographical and size delimitations (companies that are not 
included in the Brazilian Association of Supermarkets ranking) allow homogenization of the sample, which contributes to a greater robustness of the findings.

\section{Methodological procedures}

In order to evaluate and measure efficiency different approaches may be applied to get the expected results, such as the econometric emphasis, the construction of indices of total factor productivity and linear programming (Souza \& Wilhelm, 2009). However, in this study we chose to use the data envelopment analysis methodology, as a function of the variables characteristics and to avoid problems that violate the ordinary least squares assumptions, such as: multicollinearity, endogeneity and heteroscedasticity. In addition, the use of DEA is in line with the objective of this study to structure a comparative ranking of supermarket units.

The supermarket sector uses gross sales or net profit as its main valuation indexes, as shown by the Brazilian Association of Supermarkets ranking. However, these isolated variables can lead to distortions in the search for the best results on efficiency, since, according to Figueiredo \& Mello (2009, p. 286), "[...] they do not provide a clear view of the focal points for the improvement of results, offering only indicatives for reduction costs and / or margin increase".

The variables used in this work were selected from reference studies (Souza et al., 2010; Melo et al., 2018) and Sonza \& Ceretta (2008) and Figueiredo \& Mello (2009) and are the following:

a) Output variable: gross sales. Even though Angelo \& Silveira (1997) warn that other variables could be considered as output (such as the number of commercial transactions, the value added and the gross margin), it was considered that all these factors may be correlated with gross sales and are more difficult to obtain. Besides, gross sales has been the most widely used variable in studies of this sector;

b) Input variables: area of sales $\left(\mathrm{m}^{2}\right)$, number of checkouts (cash terminals) and number of employees.

Data related to the variables selected for the years 2014 and 2015 were obtained by the authors, via telephone contact, along with the 31 (thirty one) companies that agreed to participate in the study, setting up a sample for convenience. The software used for calculations was SIAD. For more information on the procedure and software consult Meza et al. (2005a, b).

In the sample composed of these 31 DMUs, the respective efficiency was measured in the two years under analysis in order to rank the units and to know which variables influence their efficiency or inefficiency. Small units were considered to have up to 3000 square meters of sales area, a parameter somewhat wider than the classification used in Sonza \& Ceretta (2008), which was based on Wedekin \& Neves (1995).

As in Barros \& Alves (2003), the consistency of the analysis was assured, since the number of DMUs was 3 times greater than the sum of the number of inputs and outputs.

The main factors to be analyzed in the evaluation of the productive efficiency of a company are the scale and technique. The first is the component of the productive efficiency that is associated to the variations of productivity due to changes in the scale of operation. On the other hand, the second is the component of productive efficiency resulting from the isolation of scale effects. Problems of technical efficiency (inefficiency) may be associated, for example, to managers' managerial ability. 
In this study, the two models (BCC and CCR) with output orientation were chosen to allow the analysis of technical and scale efficiency, as well as the studies of Barros \& Alves (2003), Barros (2006), Sellers-Rubio \& Mas Ruiz (2006), Ferreira et al. (2009), Yu \& Ramanathan (2009). The scale efficiency calculation is performed by the ratio between the efficiency of the CCR model and the efficiency of the BCC model, according to Equation 7. It makes it possible to identify if the DMUs are operating at their optimum scale and whether the units have constant returns to scale or not.

In the supermarket sector, which faces an oligopolistic competition structure, companies, especially the small ones, are expected to operate with non-constant returns to scale. This can occur due to the emergence of opportunities created by specialization in the use of work, for example.

With that being said, based on the results of the analysis of the DMU's scale efficiency, in addition to the characteristics of the supermarket sector and the purpose of evaluating technical aspects that interfere in efficiency, the model chosen for this study was the BCC, as in Badin (1997), Didonet \& Villavicencio (2008), Figueiredo \& Mello (2009), Reiner et al. (2013) and Ko et al. (2017).

Another concept used in this study is the slack (input/output slack). According to Ferreira \& Gomes (2012), excesses in the use of inputs or production below the maximum can be considered as slacks. In a situation where there is a slack (of inputs or output), the production is being inefficient.

\section{Data analysis}

Analyzing the statistics in Table 1 it is possible to notice that the data did not present standard deviation and high coefficients of variation. The average number of checkouts does not appear to change significantly from the year 2014 to the year 2015, even with the area's elevation. It is not possible to make assertions about the evolution of these data, but a plausible answer could be the need to provide other services or improve the quality of care. The increase in gross sales may be related to two facts: high inflation in the period $(2014,6.41 \%$ and $2015,10.67 \%)$; and / or a gain in the market of large supermarkets. The last one is the least likely, because, as seen in previous studies, large supermarkets are more efficient than small / medium sized supermarkets.

Table 1. Descriptive statistics.

\begin{tabular}{|c|c|c|c|c|c|c|c|c|}
\hline & \multicolumn{4}{|c|}{2014} & \multicolumn{4}{|c|}{2015} \\
\hline & \begin{tabular}{l}
$n$ \\
$\vdots$ \\
\multirow{3}{0}{} \\
$\frac{0}{0}$ \\
$\frac{0}{0}$
\end{tabular} & 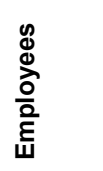 & 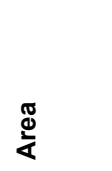 & 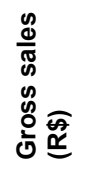 & $\begin{array}{l}n \\
\vdots \\
0 \\
\frac{7}{d} \\
\frac{d}{0}\end{array}$ & 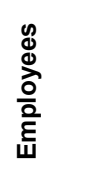 & 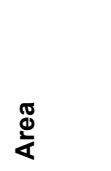 & 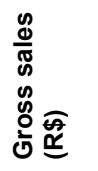 \\
\hline Mean & 5.03 & 22.68 & 775.74 & $\begin{array}{c}6,043,7 \\
44.68\end{array}$ & 5.19 & 22.65 & 802.23 & $\begin{array}{c}6,640,3 \\
15.13\end{array}$ \\
\hline $\begin{array}{l}\text { Standard } \\
\text { deviation }\end{array}$ & 4.73 & 32.55 & 591.62 & $\begin{array}{c}6,883,9 \\
17.07\end{array}$ & 4.98 & 28.45 & 615.70 & $\begin{array}{c}7,704,5 \\
35.60\end{array}$ \\
\hline $\begin{array}{l}\text { Coefficient } \\
\text { of variation }\end{array}$ & $93.98 \%$ & $\begin{array}{c}143.52 \\
\%\end{array}$ & $76.26 \%$ & $\begin{array}{c}113.90 \\
\%\end{array}$ & $95.94 \%$ & $\begin{array}{c}125.63 \\
\%\end{array}$ & $76.75 \%$ & $\begin{array}{c}116.03 \\
\%\end{array}$ \\
\hline
\end{tabular}

Source: Elaborated by authors. 
With DEA's approach, it was possible to detect different efficiency indexes in the three metrics in the years investigated (efficient units in Table 2). The results of the year 2014 presented $16.13 \%, 54.84 \%$ and $16.13 \%$ of efficiency of the DMUs evaluated by the CCR, BCC and scale efficiency models, respectively. In the year of 2015 the only value that changed was the scale efficiency, presenting a value of $19.35 \%$ efficient units.

Table 2. Maximum efficiency in units.

\begin{tabular}{|c|c|c|c|c|c|c|c|c|c|c|c|c|}
\hline & Model & DMU & DMU & DMU & DMU & DMU & DMU & DMU & DMU & DMU & Total & $\begin{array}{c}\% \text { of } \\
\text { Model }\end{array}$ \\
\hline \multirow{4}{*}{$\underset{\sim}{ষ}$} & \multirow{2}{*}{$\mathrm{BCC}$} & 1 & 2 & 4 & 5 & 6 & 7 & 8 & 10 & 11 & \multirow{2}{*}{17} & \multirow{2}{*}{$54.84 \%$} \\
\hline & & 13 & 14 & 16 & 18 & 24 & 27 & 29 & 30 & & & \\
\hline & CCR & 5 & 7 & 10 & 11 & 27 & & & & & 5 & $16.13 \%$ \\
\hline & Scale & 5 & 7 & 10 & 11 & 27 & & & & & 5 & $16.13 \%$ \\
\hline \multirow{4}{*}{ 오 } & \multirow{2}{*}{$\mathrm{BCC}$} & 1 & 2 & 4 & 5 & 6 & 7 & 8 & 10 & 11 & \multirow{2}{*}{17} & \multirow{2}{*}{$54.84 \%$} \\
\hline & & 13 & 14 & 16 & 18 & 20 & 24 & 27 & 30 & & & \\
\hline & CCR & 5 & 7 & 11 & 20 & 27 & & & & & 5 & $16.13 \%$ \\
\hline & Scale & 5 & 7 & 11 & 20 & 27 & 29 & & & & 6 & $19.35 \%$ \\
\hline
\end{tabular}

Source: Elaborated by authors.

The results show that $16.13 \%$ of DMUs in 2014 and $19.35 \%$ in 2015 are not operating in their optimal scale. These results suggest that, even for a relatively homogeneous sample (same state and close sized units), most DMUs in this sector have non-constant returns to scale. A possible explanation is that these small units may be operating in a region of increasing marginal productivity of the factors of production (specialization in the use of labor) because they are in the early stages of a nonlinear production function. A theoretical example for this type of production function is cobb-douglas, widely used in economics (Pindyck \& Rubinfeld, 2010). Comparing units with similar scales, isolating this influence, $54.84 \%$ of the DMUs for the two years investigated presented pure technical efficiency (measured by the BCC model).

From another angle, Table 3 shows the scores of all DMUs analyzed in the three metrics, segregated by year.

Table 3. Scores of analyzed data.

\begin{tabular}{ccccccc}
\hline \multirow{2}{*}{ DMU } & \multicolumn{3}{c}{$\mathbf{2 0 1 4}$} & \multicolumn{3}{c}{$\mathbf{2 0 1 5}$} \\
\cline { 2 - 6 } & CCR & BCC & Scale & CCR & BCC & Scale \\
\hline DMU_01 & 0.6750 & 1.0000 & 0.6750 & 0.6684 & 1.0000 & 0.6684 \\
\hline DMU_02 & 0.6829 & 1.0000 & 0.6829 & 0.6264 & 1.0000 & 0.6264 \\
\hline DMU_03 & 0.6782 & 0.8756 & 0.7746 & 0.6692 & 0.8386 & 0.7980 \\
\hline DMU_04 & 0.8764 & 1.0000 & 0.8764 & 0.9227 & 1.0000 & 0.9227 \\
\hline DMU_05 & 1.0000 & 1.0000 & 1.0000 & 1.0000 & 1.0000 & 1.0000 \\
\hline DMU_06 & 0.4958 & 1.0000 & 0.4958 & 0.4485 & 1.0000 & 0.4485 \\
\hline DMU_07 & 1.0000 & 1.0000 & 1.0000 & 1.0000 & 1.0000 & 1.0000 \\
\hline DMU_08 & 0.6562 & 1.0000 & 0.6562 & 0.6290 & 1.0000 & 0.6290 \\
\hline
\end{tabular}


Table 3. Continued...

\begin{tabular}{|c|c|c|c|c|c|c|}
\hline \multirow{2}{*}{ DMU } & \multicolumn{3}{|c|}{2014} & \multicolumn{3}{|c|}{2015} \\
\hline & CCR & BCC & Scale & CCR & BCC & Scale \\
\hline DMU_09 & 0.8135 & 0.9392 & 0.8662 & 0.7770 & 0.9192 & 0.8453 \\
\hline DMU_10 & 1.0000 & 1.0000 & 1.0000 & 0.4552 & 1.0000 & 0.4552 \\
\hline DMU_11 & 1.0000 & 1.0000 & 1.0000 & 1.0000 & 1.0000 & 1.0000 \\
\hline DMU_12 & 0.5339 & 0.6979 & 0.7649 & 0.5477 & 0.7154 & 0.7656 \\
\hline DMU_13 & 0.8018 & 1.0000 & 0.8018 & 0.7943 & 1.0000 & 0.7943 \\
\hline DMU_14 & 0.6997 & 1.0000 & 0.6997 & 0.6360 & 1.0000 & 0.6360 \\
\hline DMU_15 & 0.5948 & 0.9202 & 0.6464 & 0.6328 & 0.9372 & 0.6752 \\
\hline DMU_16 & 0.6700 & 1.0000 & 0.6700 & 0.4383 & 1.0000 & 0.4383 \\
\hline DMU_17 & 0.7217 & 0.7506 & 0.9615 & 0.5429 & 0.8175 & 0.6642 \\
\hline DMU_18 & 0.9179 & 1.0000 & 0.9179 & 0.7955 & 1.0000 & 0.7955 \\
\hline DMU_19 & 0.5809 & 0.6351 & 0.9146 & 0.5769 & 0.6093 & $0.946 \mathrm{~s}$ \\
\hline DMU_20 & 0.8919 & 0.9614 & 0.9277 & 1.0000 & 1.0000 & 1.0000 \\
\hline DMU_21 & 0.5921 & 0.8768 & 0.6753 & 0.5996 & 0.8723 & 0.6874 \\
\hline DMU_22 & 0.5580 & 0.8142 & 0.6853 & 0.5576 & 0.8012 & $0.695 \mathrm{~s}$ \\
\hline DMU_23 & 0.7135 & 0.8904 & 0.8013 & 0.6918 & 0.8694 & 0.7957 \\
\hline DMU_24 & 0.5633 & 1.0000 & 0.5633 & 0.5328 & 1.0000 & 0.5328 \\
\hline DMU_25 & 0.6089 & 0.7673 & 0.7935 & 0.6665 & 0.7369 & 0.9044 \\
\hline DMU_26 & 0.8609 & 0.8853 & 0.9725 & 0.8868 & 0.9139 & 0.9704 \\
\hline DMU_27 & 1.0000 & 1.0000 & 1.0000 & 1.0000 & 1.0000 & 1.0000 \\
\hline DMU_28 & 0.6387 & 0.6975 & 0.9158 & 0.6152 & 0.6530 & 0.9421 \\
\hline DMU_29 & 0.7671 & 1.0000 & 0.7671 & 0.9536 & 0.8718 & 1.0000 \\
\hline DMU_30 & 0.6753 & 1.0000 & 0.6753 & 0.6281 & 1.0000 & 0.6281 \\
\hline DMU_31 & 0.4229 & 0.5515 & 0.7669 & 0.4120 & 0.5366 & 0.7677 \\
\hline
\end{tabular}

Source: Elaborated by authors.

As it is shown in Table 3, some DMUs presented equal scores, regardless of the used model (regardless of being equal to 1,00 ). This means, for example, that for these DMUs, the evaluation in terms of the constant returns (CCR model) or the scale variables (BCC) would not have different results, as in the cases of DMUs "05", "07" and "11".

It is also possible to conclude by the results, via $\mathrm{BCC}$, that the hypothesis of variable returns to scale is accepted, as it occurred with the DMU "01". That is, this unit did not present maximum efficiency in the CCR model $(0,6750)$, but presented full efficiency in the BCC model. This means that its inefficiency is due to the inadequate scale of production (scale efficiency equal to 0,6684 ). This means that the inefficiency of scale tells us how far it is from the optimal scale and that it would be possible, by varying the size of the DMU's operations, to get to that optimal point.

Normally, the results indicate, as in studies by Souza et al. (2010) and Barros \& Alves (2003), that inefficiency of scale is a determining factor in the performance problem of Brazilian supermarket units (in this case, small and from Santa Catarina).

In addition to the determination of efficiency, it was also possible to identify which variables influenced the results. The ones that presented a slack in the performance of the stores that did not reach efficiency were the "Sales area" and the number of "Employees". In general, it can be identified that the slacks are directly related to the variables related to the size of the units. Even though it is a specific analysis for small units in Santa Catarina, this conclusion is in line with the findings of Yu \& Angelo (2001), Barros (2006) and Souza et al. (2010). 
These impacts can be observed in numerical terms in Table 4, which refers specifically to the BCC model.

Table 4. DMUs with slacks in variables.

\begin{tabular}{|c|c|c|c|c|c|c|c|}
\hline \multicolumn{4}{|c|}{ 2014/BCC } & \multicolumn{4}{|c|}{ 2015/BCC } \\
\hline \multirow{2}{*}{$\begin{array}{l}\text { inefficient DMU / } \\
\text { value }\end{array}$} & \multicolumn{3}{|c|}{ Variables with slack } & \multirow{2}{*}{$\begin{array}{l}\text { inefficient DMU / } \\
\text { value }\end{array}$} & \multicolumn{3}{|c|}{ Variables with slack } \\
\hline & Check & Empl & Area & & Check & Empl & Area \\
\hline DMU_03(0.875611) & 0.00 & 0.00 & 10.05 & DMU_03(0.838554) & 0.00 & 0.00 & 85.17 \\
\hline DMU_09(0.939164) & 0.00 & 0.00 & 0.00 & DMU_09(0.919223) & 0.00 & 0.00 & 0.00 \\
\hline DMU_12(0.697928) & 0.00 & 0.00 & 2.77 & DMU_12(0.715407) & 0.00 & 0.00 & 66.64 \\
\hline DMU_15(0.920163) & 0.00 & 3.17 & 73.69 & DMU_15(0.937185) & 0.00 & 2.36 & 86.29 \\
\hline DMU_17(0.750553) & 0.00 & 0.00 & 0.00 & DMU_17(0.817461) & 0.00 & 4.71 & 0.00 \\
\hline DMU_19(0.635138) & 0.00 & 0.00 & 0.00 & DMU_19(0.609290) & 0.00 & 0.00 & 0.00 \\
\hline DMU_20(0.961406) & 0.00 & 0.00 & 147.52 & DMU_21(0.872319) & 0.00 & 0.00 & 68.51 \\
\hline DMU_21(0.876769) & 0.00 & 0.29 & 56.56 & DMU_22(0.801206) & 0.00 & 2.30 & 0.00 \\
\hline DMU_22(0.814239) & 0.00 & 3.58 & 0.00 & DMU_23(0.869424) & 0.00 & 0.00 & 29.99 \\
\hline DMU_23(0.890352) & 0.00 & 0.00 & 0.00 & DMU_25(0.736916) & 0.00 & 5.09 & 0.00 \\
\hline DMU_25(0.767347) & 0.00 & 3.60 & 0.00 & DMU_26(0.913862) & 0.00 & 7.73 & 0.00 \\
\hline DMU_26(0.885298) & 0.00 & 3.07 & 0.00 & DMU_28(0.653046) & 0.00 & 0.00 & 0.00 \\
\hline DMU_28(0.697484) & 0.00 & 0.00 & 0.00 & DMU_29(0.871795) & 0.00 & 1.38 & 0.00 \\
\hline DMU_31(0.551477) & 0.00 & 0.00 & 5.06 & DMU_31(0.536620) & 0.00 & 0.00 & 53.92 \\
\hline
\end{tabular}

Source: Elaborated by authors.

These slacks resulting from the application of modeling may represent, to some extent, an idle structural capacity. That is, the DMUs that presented slacks in the identified variables, based on the gross sales, tend to be less efficient than those that demonstrated to be efficient.

Given this, it is possible to analyze that, in the case of the units with slacks in the number of employees, the comparison with the benchmarks (desired levels of performance) shows that their gross sales per employee was below the weight found in the best placed ones. The same occurred in the case of the "Sales area" variable, when a structural capacity greater than the achieved gross sales is used.

It is important to highlight the contribution of this study through its findings in three main points: the low index of units that operate at maximum / full efficiency, the high inefficiency of scale and the identification of the intrinsic variables in the model that obtained greater slacks, that is, idle capacity of input. This allows a greater knowledge for managers of the units of this sector, indicating a direction so that the management of resources is carried out in a better way, which can contribute to a greater efficiency of its managed units.

\section{Conclusions}

This study aimed to analyze the efficiency of a sample of the small supermarkets in the Santa Catarina, as well as to verify the variables that had the greatest impact on the performance of the analyzed units. The period under analysis was the years 2014 and 2015, with data obtained by the authors from the 31 (thirty one) companies that agreed to provide their information. From these data, three metrics mentioned in the tables of the previous sections were calculated. 
The findings showed a low frequency of supermarkets with maximum frontier efficiency, as well as an idle capacity in the structural formation of their stores. That being said, it gets clear the need for a deeper verification by the managers about the performance of their stores, in order to optimize the potential of generating the prioritized product / output (increase in gross sales), keeping the "inputs" selected constant. This gains special attention because it is a regionally oligopolized sector, which has large groups of "leading" companies that have a significant market share and can compete directly via price.

Given this results, it is considered that the study contributed to highlight the importance of the application of this methodology in the analysis of the performance of supermarkets. This is due to the simultaneous analysis of several important variables in determining company's revenue, which makes the method more robust and reliable for a ranking and efficiency analysis than other commonly used strategies.

As to the limitations that can be attributed to this study, it is possible to mention that the methodology used, as it is a non-parametric technique, does not allow such an in-depth conclusion, and the comparative analysis is restricted to the units and variables under analysis. In addition, the dataset is small, so the conclusions are limited to the sample investigated. In order to generalize the findings, a larger sample would be needed.

A next step, following this study, would be to evaluate productive arrangements (shopping networks) or even, supermarket chains of the same economic group. In this kind of sample, its homogeneity is even more present, allowing the inclusion of more variables, such as the rupture index, employees' turnover rates and margins, for example. Besides, it would be possible to apply the combination of the DEA method with other methodologies, in two stages.

\section{References}

Angelo, C. F., \& Silveira, J. A. G. (1997). Varejo competitivo. São Paulo: Atlas.

Badin, N. T. (1997). Avaliação da produtividade de supermercados e seu benchmarking (Dissertação de mestrado). Universidade Federal de Santa Catarina, Florianópolis.

Banker, R. D., Charnes, A., \& Cooper, W. (1984). Some models for estimating technical and scale inefficiencies, in data envelopment analysis. Management Science, 30(9), 10781092. http://dx.doi.org/10.1287/mnsc.30.9.1078.

Barros, C. P. (2006). Efficiency measurement among hypermarkets and supermarkets and the identification of the efficiency drivers: a case study. International Journal of Retail \& Distribution Management, 34(2), 135-154. http://dx.doi.org/10.1108/09590550610649795.

Barros, C. P., \& Alves, C. A. (2003). Hypermarket retail store efficiency in Portugal. International Journal of Retail \& Distribution Management, 31(11), 549-560. http://dx.doi.org/10.1108/09590550310503285.

Boueri, R., Rocha, F., \& Rodopoulos, F. (2015). Avaliação da qualidade do gasto público e mensuração da eficiência. Brasília: Tesouro Nacional.

Charnes, A., Cooper, W. W., \& Rhodes, E. (1978). Measuring the efficiency of decision-making units. European Journal of Operational Research, 2(6), 429-444. http://dx.doi.org/10.1016/0377-2217(78)90138-8.

Colin, E. C. (2007). Pesquisa operacional: 170 aplicações em estratégia, finanças, logística, produção, marketing e vendas. Rio de Janeiro: LTC.

Cooper, W. W., Seiford, L. M., \& Tone, K. (2007). Data envelopment analysis: a comprehensive text with models, applications, references and DEA-solver software (2nd ed.). Boston: Springer. 
Departamento Intersindical de Estatística e Estudos Socioeconômico - DIEESE. (2016). Comércio em 2015: um balanço dos principais indicadores (Boletim de Indicadores do Comércio, pp. 1-21). São Paulo. Retrieved in 2017, June 21, from http://www.apcefsp.org.br/portal/data/files/30/02/B7/FE/2F3C4510F6EA9B45203A91A8/DI EESE\%20-\%20Boletim\%20Indicadores\%20Comercio\%2008\%20-\%202016-05-16.pdf

Didonet, S. R., \& Villavicencio, G. J. D. (2008). Orientación al mercado y eficiencia en los supermercados: evidencias empíricas. Revista de Administração da UFSM, 1(1), 134-152. http://dx.doi.org/10.5902/19834659579.

Donthu, N., \& Yoo, B. (1998). Retail productivity assessment using data envelopment analysis. Journal of Retailing, 74(1), 89-105. http://dx.doi.org/10.1016/S0022-4359(99)80089-X.

Estrada, R. J. S., \& Almeida, M. I. R. (2007). A eficiência e a eficácia da gestão estratégica: do planejamento estratégico à mudança organizacional. Revista de Ciências da Administração, 9(19), 147-178. http://dx.doi.org/10.5007/\%25x.

Farrell, M. J. (1957). The measurement of productive efficiency. Journal of the Royal Statistical Society. Series A, (Statistics in Society), 120(3), 253-290. http://dx.doi.org/10.2307/2343100.

Ferreira, C. M. C., \& Gomes, A. P. (2012). Análise envoltória de dados: teoria, modelos e aplicações. Viçosa: Editora da UFV.

Ferreira, M. A. M., Venâncio, M. M., \& Abrantes, L. A. (2009). Análise da eficiência do setor de supermercados no Brasil. Economia Aplicada, 13(2), 333-347. http://dx.doi.org/10.1590/S1413-80502009000200007.

Ferreira, R. N., Santos, A. C., Lopes, A. L. M., Nazareth, L. G. C., \& Fonseca, R. A. (2013). Governança corporativa, eficiência, produtividade e desempenho. Revista de Administração Mackenzie, 14(4), 134-164. http://dx.doi.org/10.1590/S167869712013000400006.

Figueiredo, D. S., \& Mello, J. C. C. B. S. (2009). Índice híbrido de eficácia e eficiência para lojas de varejo. Gestão \& Produção, 16(2), 286-300. http://dx.doi.org/10.1590/S0104$530 \times 2009000200011$.

Johnston, J., \& Dinardo, J. (2001). Métodos de econometría. Barcelona: Vicens Vives.

Ko, K., Chang, M., Bae, E., \& Kim, D. (2017). Efficiency analysis of retail chain stores in Korea. Sustainability, 9(9), 1629. http://dx.doi.org/10.3390/su9091629.

Melo, F. L. N., Sampaio, R. M. B., \& Sampaio, L. M. B. (2018). Efficiency, productivity gains, and the size of Brazilian supermarkets. International Journal of Production Economics, 197, 99-111. http://dx.doi.org/10.1016/j.ijpe.2017.12.016.

Meza, L. A., Biondi, L. No., Mello, J. C. C. B. S., \& Gomes, E. G. (2005a). Isyds - Integrated System for Decision Support (Siad - Sistema Integrado De Apoio a Decisão): a software package for data envelopment analysis model. Pesquisa Operacional, 25(3), 493-503. http://dx.doi.org/10.1590/S0101-74382005000300011.

Meza, L. A., Biondi, L. No., Mello, J. C. C. B. S., Gomes, E. G., \& Coelho, P. H. G. (2005b). Free software for decision analysis: a software package for data envelopment models. In Proceedings of the Seventh International Conference on Enterprise Information Systems (pp. 207-212). Portugal: Science and Technology Publications.

Moreno, J. J. (2006). Regional regulation analysis of performance in Spanish retailing. International Journal of Retail \& Distribution Management, 34(10), 773-793. http://dx.doi.org/10.1108/09590550610691356.

Moreno, J. J. (2008). Efficiency and regulation in Spanish hypermarket retail trade: a crosssection approach. International Journal of Retail \& Distribution Management, 36(1), 71-88. http://dx.doi.org/10.1108/09590550810847009. 
Parsons, L. J. (1997). Productivity versus relative efficiency in marketing: past and future. In G. Laurent, G. L. Lilien \& B. Pras (Eds.), Research traditions in marketing (pp. 96-168). Boston: Kluwer.

Pindyck, R. S., \& Rubinfeld, D. L. (2010). Microeconomia (7. ed.). São Paulo: Prentice Hall.

Reiner, G., Teller, C., \& Kotzab, H. (2013). Analyzing the efficient execution of in-store logistics processes in grocery retailing: the case of dairy products. Production and Operations Management, 22(4), 924-939. http://dx.doi.org/10.1111/poms.12003.

Sellers-Rubio, R., \& Mas-Ruiz, F. (2006). Economic efficiency in supermarkets: evidences in Spain. International Journal of Retail \& Distribution Management, 34(2), 155-171. http://dx.doi.org/10.1108/09590550610649803.

Silva, H. B. F., \& Qassim, R. Y. (1994). Data envelopment analysis: uma ferramenta para o benchmarking. Revista Brasileira de Pesquisa Operacional, 15(1).

Sinik, N. (2017). Assessing organizational efficiency via data envelopment analysis in the Austrian supermarket sector. In Proceedings of the 8th Annual Global Business Conference. Dubrovnik: GBC.

Sonza, I. B., \& Ceretta, P. S. (2008). Utilização do DEA para análise da eficiência nos supermercados brasileiros. In Anais do Congresso USP de Iniciação Científica em Contabilidade. São Paulo: USP.

Souza, M. A. F., Macedo, M. A. S., \& Ferreira, M. S. (2010). Desempenho organizacional no setor supermercadista brasileiro: uma análise apoiada em dea. Revista de Gestão, 17(2), 151-167. http://dx.doi.org/10.5700/rege392.

Souza, P. C. T., \& Wilhelm, V. E. (2009). Uma introdução aos modelos DEA de eficiência técnica. Ciência e Cultura, 42, 121-139.

Szczepura, A., Davies, C., Fletcher, J., \& Boussofiane, A. (1993). Efficiency and Effectiveness in general practice. Journal of Management in Medicine, 7(5), 36-47. http://dx.doi.org/10.1108/eb060565.

Thompson, A. A., \& Formby, J. P. (2003). Microeconomia da firma: teoria e prática (6. ed.). Rio de Janeiro: LTC.

Varian, H. R. (2012). Microeconomia: uma abordagem moderna (8. ed.). Rio de Janeiro: Elsevier.

Wedekin, I., \& Neves, M. F. (1995). Sistema de distribuição de alimentos: o impacto das novas tecnologias. Revista de Administração da Universidade de São Paulo, 4(30), 5-18.

Yu, A. S. O., \& Angelo, C. F. (2001). Performance of Brazilian supermarkets: a comparative analysis between large and small store chains. Journal of Small Business and Enterprise Development, 8(4), 339-348. http://dx.doi.org/10.1108/EUM0000000006829.

Yu, W., \& Ramanathan, R. (2009). An assessment of operational efficiency of retail firms in China. Journal of Retailing and Consumer Services, 16(2), 109-122. http://dx.doi.org/10.1016/j.jretconser.2008.11.009. 